\title{
Inhibition of human seminal fluid DNA polymerase by an IgG fraction of seminal plasma from vasectomized men
}

\author{
P. J. Higgins, S. S. Witkin and A. Bendich
}

Laboratory of Cell Biochemistry, Memorial Sloan-Kettering Cancer Center, 1275 York Avenue, New York, New York 10021, U.S.A.

\begin{abstract}
Summary. Immunoglobulin G (IgG) was isolated from ejaculates of intact and vasectomized men by precipitation with ammonium sulphate and DEAE-cellulose ionexchange chromatography. Velocity centrifugation revealed that all of the IgG from intact males was $7 \mathrm{~S}$ protein while $<40 \%$ of the seminal IgG of vasectomized men cosedimented with the 7S marker; the remaining, immunologically unidentifiable, protein was considerably smaller and heterogeneous in size. Only the $7 \mathrm{~S} \mathrm{IgG} \mathrm{from} \mathrm{the}$ post-vasectomy ejaculates inhibited the activity of a DNA polymerase from the seminal fluid of an intact male. These results suggest that formation of antibody reactive with the seminal fluid DNA polymerase is one manifestation of a vasectomy-associated autoimmune response in man.
\end{abstract}

\section{Introduction}

In men, humoral and cell-mediated autoimmune responses are known to result from exposure to autologous spermatozoa (Cochran, 1974; Hekman \& Rumke, 1976; Mettler, Gradl \& Scheidel, 1976; Katsh \& Katsh, 1977). Although such auto-sensitization to sperm antigens may occur under pathological conditions, vasectomy, a procedure widely employed as a method of fertility control, produces similar effects. Morphological alterations within the male reproductive tract, including granuloma formation and macrophage infiltration (Edwards, 1976), as well as sperm-directed autoimmunological reactions, are frequent consequences of vasectomy (Ansbacher, 1971; Coombs, Rumke \& Edwards, 1973; Shulman, 1974; Alexander, 1975, 1976, 1977; Alexander \& Schmidt, 1977). Antibodies to sperm nuclear antigen(s) can develop after vasectomy (Tung, 1975) and at least one sperm auto-antigen has been identified as protamine (Kolk, Samuel \& Rumke, 1974). Auto-antibodies may be produced to previously sequestered sperm antigens because of the accumulation and phagocytosis of spermatozoa after vasectomy (Edwards, 1976), or perhaps in response to extravasation and granuloma formation.

Human seminal fluid and membrane-free sperm nuclei contain DNA-synthesizing complexes which are antigenically related (Witkin \& Higgins, 1978), ribonuclease-sensitive and actinomycin D-resistant (Witkin, Korngold \& Bendich, 1975; Witkin \& Bendich, 1977). Anlaysis of semen from the same donors before and after vasectomy revealed a 3-4-fold post-operative decrease in the DNAsynthesizing activity of cell-free seminal fluid (Witkin \& Higgins, 1978). Since the enzymic properties of the seminal fluid complex could be inhibited by antiserum to purified sperm nuclei (Witkin \& Higgins, 1978), this suggested that the decrease in seminal fluid DNA-synthesizing activity might be due to the presence of DNA polymerase auto-antibodies. To test directly whether immunoglobulins capable of inhibiting the activity of the seminal fluid complex were present in the semen of vasectomized men, immunoglobulin $\mathrm{G}$ (IgG) was purified from the cell-free seminal fluid of intact and vasectomized males, and its effect on DNA polymerase activity was tested.

\section{Materials and Methods}

\section{Preparation of seminal $\operatorname{IgG}$}

Multiple ejaculates were obtained from 10 healthy medical student donors. Seminal fluid from vasectomized men was obtained from the Margaret Sanger Center, Planned Parenthood of New 
York City, Inc. An equal volume of glycerol was added to each fresh specimen before storage at $-20^{\circ} \mathrm{C}$. After thawing, 30 samples of each type of semen were pooled to give about $100 \mathrm{ml}$ semenglycerol.

Cellular elements were removed from the seminal fluid of vasectomized men (V) and whole semen (W) by centrifugation at $2000 \mathrm{~g}$ for $20 \mathrm{~min}$. The supernatants were further clarified by re-centrifugation at $15000 \mathrm{~g}$ for $20 \mathrm{~min}$. The resulting supernatants were brought to $33 \%$ saturation with neutral ammonium sulphate (Campbell, Garvey, Cremer \& Sussdorf, 1970), stirred for $4 \mathrm{~h}$ at $5^{\circ} \mathrm{C}$, and centrifuged at $5000 \mathrm{~g}$ for $20 \mathrm{~min}$. The pellets were resuspended in $5 \mathrm{ml} 0.01 \mathrm{M}$-sodium phosphate buffer, $\mathrm{pH} 7 \cdot 5$, and dialysed exhaustively against this buffer. The dialysed preparations were centrifuged at $10000 \mathrm{~g}$ for $20 \mathrm{~min}$ at $4^{\circ} \mathrm{C}$ and subjected to chromatography on DEAE-cellulose (Campbell et al., 1970). Fractions contributing to the single peak recoverable by ion-exchange chromatography were pooled, concentrated to $1 \mathrm{mg}$ protein $/ \mathrm{ml}$ with the use of Millipore Immersible Separators and dialysed against $0.1 \mathrm{M}$-Tris- $\mathrm{HCl}$ buffer, $\mathrm{pH} 7 \cdot 5$. Protein concentration was determined by the method described by Shatkin (1969). Immunological identification of IgG was by agar double-diffusion in Immunoplates (Pattern D: Hyland Laboratories, Costa Mesa, California) and immunoelectrophoresis in $1 \%(\mathrm{w} / \mathrm{v})$ agarose with Beckman B-2 barbiturate buffer, $\mathrm{pH} 8.6$, at $20 \mathrm{~mA}$ and $200 \mathrm{~V}$ for $50 \mathrm{~min}$. Antisera raised in goats to whole human serum and human IgG were purchased from Cappel Laboratories, Cochranville, Pennsylvania. Antisera to human IgM and IgA were obtained from Behring Diagnostics (Woodbury, New York). Precipitin patterns were stained with amido-black 10B (Lardinois \& Page, 1969) after incubation at $37^{\circ} \mathrm{C}$ for $72 \mathrm{~h}$. The isolated IgGs were layered on $4 \mathrm{ml} 10-40 \%(\mathrm{w} / \mathrm{v})$ sucrose/phosphate-buffered saline gradients, and centrifuged at $165000 \mathrm{~g}$ at $4^{\circ} \mathrm{C}$ for $18 \mathrm{~h}$. The bottom of each tube was punctured with a 21-gauge needle and 5-drop fractions were collected. The optical density of the fractions at $280 \mathrm{~nm}$ was determined with a Beckman DU spectrophotometer. Peak absorbance fractions were pooled, dialysed against $0 \cdot 1 \mathrm{M}-\mathrm{Tris}-\mathbf{H C l}, \mathrm{pH} 7 \cdot 5$, and examined for DNA polymerase inhibitory activity. Aliquots of these fractions were adjusted to $0.4 \mathrm{mg}$ protein $/ \mathrm{ml}$ Tris buffer for immunochemical analysis.

\section{Seminal fluid DNA polymerase isolation}

Purification of the seminal fluid DNA polymerase from a single normal ejaculate has been lescribed in detail elsewhere (Witkin \& Higgins, 1978). Briefly, the semen was diluted 3-fold in 0.01 M-Tris- $\mathrm{HCl}, \mathrm{pH} 7.5,0.15 \mathrm{M}-\mathrm{NaCl}, 2 \mathrm{~mm}-\mathrm{EDTA}$, and the cell-free seminal fluid was obtained by successive centrifugations at $1500 \mathrm{~g}$ and $16000 \mathrm{~g}$. A particulate fraction was isolated from the last supernatant by sedimentation through an $18 \%(\mathrm{w} / \mathrm{v})$ Metrizamide solution (Accurate Chemical and Scientific Corp., Hicksville, New York). DNA polymerase in the Metrizamide pellet fraction was solubilized with $0 \cdot 5 \%$ Triton X-100, $0.8 \mathrm{M}-\mathrm{KCl}, 0.01 \mathrm{M}$-dithiothreitol and fractionated by gel filtration on Ultrogel AcA 44 (12 000-130000 molecular weight fractionation range; LKB Instruments Inc., Rockville, Maryland). One peak of DNA polymerase activity, assayed with the synthetic template $\mathrm{dT}_{12-18} \cdot$ poly rA (P-L Biochemicals, Milwaukee, Wisconsin), was identified just after the void volume. The peak fractions were diluted with an equal volume of glycerol and stored at $-20^{\circ} \mathrm{C}$.

\section{Inhibition of DNA polymerase activity}

The effect of IgG on the seminal fluid DNA polymerase activity was assessed in two ways. In the first, IgG isolated from the seminal fluid of vasectomized males was mixed in various proportions with IgG derived from the serum of a normal male donor, with no previous history of surgery, so that each sample tested contained a total of $50 \mu \mathrm{g} \mathrm{IgG.} \mathrm{In} \mathrm{the} \mathrm{second} \mathrm{test,} \mathrm{various} \mathrm{concentrations} \mathrm{of} \mathrm{IgG}$ derived from the seminal fluid of intact or vasectomized males were tested in the absence of serum IgG from a normal male. The seminal fluid enzymes were partly purified by gel filtration (see above) and were incubated with IgG, $0 \cdot 15 \mathrm{M}-\mathrm{KCl}$ and $0.01 \mathrm{M}$-dithiothreitol at $0^{\circ} \mathrm{C}$ in a total volume of $75 \mu \mathrm{l}$. After $150 \mathrm{~min}$, the samples were diluted with an equal volume of the DNA polymerase reaction mixture $\left(0.32\right.$ mM-dATP; $0.04 \mathrm{M}-\mathrm{Tris}-\mathrm{HCl}, \mathrm{pH} 7.5 ; 2 \mathrm{mM}-\mathrm{MnCl}_{2} ; 0.75 \mu \mathrm{gT}_{12-18} \cdot$ poly $\mathrm{rA} ; 7 \mu \mathrm{Ci}$ $\left[{ }^{3} \mathrm{H}\right] \mathrm{dTTP}$ (sp. act. $46 \mathrm{Ci} / \mathrm{mmol}$ : New England Nuclear, Boston, Massachusetts)) and incubated at $30^{\circ} \mathrm{C}$ for $20 \mathrm{~min}$. The reactions were terminated by the addition of a 100 -fold excess of ice-cold $5 \%$ 
$(\mathrm{v} / \mathrm{v})$ trichloroacetic acid containing $1 \%(\mathrm{w} / \mathrm{v})$ sodium pyrophosphate. After $15 \mathrm{~min}$ at $0^{\circ} \mathrm{C}$, acidinsoluble products were collected on glass-fibre filters and the radioactivity was determined (Witkin \& Bendich, 1977).

\section{Virus and viral disruption}

Simian sarcoma virus (SSV) was generously given by Dr Harry Snyder. To release the reverse transcriptase, purified virus ( $2 \mu \mathrm{g}$ protein) was disrupted in $380 \mathrm{mM}-\mathrm{KCl}, 0.3 \%$ Triton $\mathrm{X}-100$ and 10 mM-dithiothreitol by incubation at $4^{\circ} \mathrm{C}$ for at least $60 \mathrm{~min}$. To test for IgG-mediated inhibition of viral reverse transcriptase activity, the disrupted viral suspension was diluted $2 \cdot 5$-fold in solutions of $0.05 \mathrm{M}$-Tris- $\mathrm{HCl}, \mathrm{pH} \mathrm{7.5}$, containing various IgG concentrations. After incubation at $4^{\circ} \mathrm{C}$ for 150 min, exogenously templated $\left(\mathrm{dT}_{12-18} \cdot \mathrm{rA}\right)$ polymerase activity was assayed as described for seminal fluid.

\section{Isolation of IgG}

\section{Results}

The results of sucrose velocity sedimentation of aliquots of the IgG fractions obtained from Samples $\mathrm{W}$ and $\mathrm{V}$ are shown in Text-fig. 1. The IgG derived from the seminal fluid of intact males (Sample W) sedimented as a single 7S peak, but that from the vasectomized men (Sample V) gave a $7 \mathrm{~S}$ peak and another peak of more slowly sedimenting material. Immunoelectrophoretic and agar double-diffusion analyses of the pooled $7 \mathrm{~S}$ fractions of each velocity sedimentation and the more slowly sedimenting fraction of Sample $\mathrm{V}$ confirmed the identification of the $7 \mathrm{~S}$ material in both samples as IgG (Pl. 1, Figs 1 and 2). No additional precipitin arcs or spurs were seen after staining the precipitin patterns and there was no reaction with anti-IgM or anti-IgA. The material in fractions 7-9 of Sample V could not be identified by our immunological tests.

A total of $1.5 \mathrm{mg}$ protein, all apparently $7 \mathrm{~S} \mathrm{IgG}$, was isolated from approximately $50 \mathrm{ml}$ Sample $\mathrm{W}$. Of the $1.1 \mathrm{mg}$ protein obtained from the corresponding fraction of a similar volume of Sample $\mathrm{V}$, only $0.4 \mathrm{mg}$ was $7 \mathrm{~S} \mathrm{IgG}$; the remaining $0.7 \mathrm{mg}$ was protein of a considerably smaller $\mathrm{S}$ value.

\section{Inhibition of DNA polymerase activity}

IgG derived from normal male serum and Sample V were combined in various proportions to a total of $50 \mu \mathrm{g} \mathrm{IgG}$ present in each assay and tested for their effect on the seminal fluid DNA polymerase. The degree of enzyme inhibition was clearly proportional to the amount of Sample V IgG in the reaction mixture (Table 1 ).

Table 1. Inhibition of seminal fluid DNA polymerase activity by IgG derived from the semen of vasectomized men

\begin{tabular}{ccc}
\hline \multicolumn{2}{c}{ Conc. of IgG $(\mu \mathrm{g})$} & \\
\hline $\begin{array}{c}\text { From seminal fluid of } \\
\text { vasectomized men }\end{array}$ & $\begin{array}{c}\text { From serum } \\
\text { of intact men }\end{array}$ & DNA polymerase activity* \\
\hline 0 & 50 & 880 \\
10 & 40 & 721 \\
20 & 30 & 176 \\
30 & 20 & 158 \\
40 & 10 & 132 \\
50 & 0 & 88 \\
\hline
\end{tabular}

* As c.p.m. of acid-insoluble product (see text). The value of 100 c.p.m. for the polymerization of $\left[{ }^{3} \mathrm{H}\right]$ TTP in the absence of added enzyme has been subtracted from each value. 


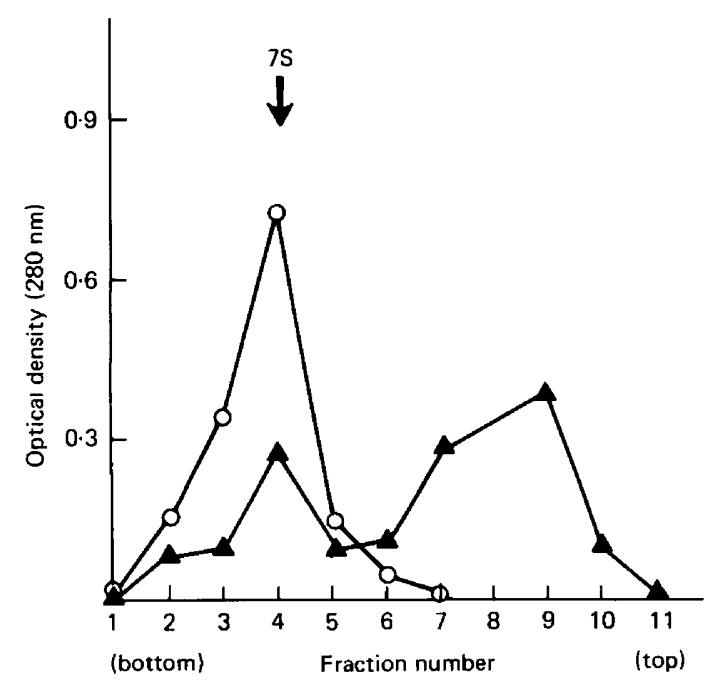

Text-fig. 1. Velocity sedimentation of the IgG isolated, by ammonium sulphate precipitation and DEAEcellulose ion-exchange chromatography, from the semen of intact $(O)$ and vasectomized $(\Delta)$ men.

To test whether the inhibition of seminal fluid DNA polymerase activity was specific to the seminal fluid IgG of vasectomized males or was also present in that from intact men, the purified $7 \mathrm{~S} \mathrm{IgGs} \mathrm{from} \mathrm{both} \mathrm{sources,} \mathrm{as} \mathrm{well} \mathrm{as} \mathrm{the}<7 \mathrm{~S}$ fraction of Sample V (see Text-fig. 1), were used individually. Because of the small amount of $7 \mathrm{~S}$ IgG present in Sample V, concentrations up to $10 \mu \mathrm{g}$ only were studied.

The 7S IgG of sample $\mathrm{W}$ and the $<7 \mathrm{~S}$ fraction of Sample V IgG did not inhibit the seminal fluid enzyme at concentrations of up to $15 \mu \mathrm{g}$ (Table 2). In contrast, $10 \mu \mathrm{g}$ of the $7 \mathrm{~S} \mathrm{IgG}$ from Sample V was sufficient to cause a $50 \%$ reduction in seminal fluid DNA polymerase activity.

\section{Discussion}

Increased serum titres of apparently naturally occurring antisperm antibodies and the appearance of an antibody directed against sperm nuclear antigen have been observed after vasectomy (Tung, 1975). Since the demonstration of the nuclear antigen required prior trypsin and dithiothreitol treatment of the spermatozoa, it is unlikely that the antigen was derived from seminal fluid or

\section{EXPLANATION OF PLATE}

Fig. 1. Immunoelectrophoretic analysis of fractions isolated from the seminal fluid of intact and vasectomized men by ion-exchange chromatography on DEAE-cellulose and sucrose velocity centrifugation. The antigen wells contained $10 \mu \mathrm{l}$ of a solution containing $0.4 \mathrm{mg}$ protein $/ \mathrm{ml}$ of the following: (S) cell-free seminal fluid; (1) reference 7S serum IgG; (2) 7S IgG isolated from the semen of intact males (Sample W); (3) IgG-containing fraction of semen from vasectomized males (Sample V); (4) the 7S IgG fraction of Sample V; (5) the $<7 \mathrm{~S}$ fraction of Sample V. Electrophoresis was carried out at $20 \mathrm{~mA}$ and $200 \mathrm{~V}$ for 50 min and then $50 \mu \mathrm{l}$ antiserum to (A) whole human serum or (B) human IgG were added to the troughs and the plate was incubated at $37^{\circ} \mathrm{C}$ for $72 \mathrm{~h}$.

Fig. 2. Agar double-diffusion test of the homology among the IgG isolates obtained from human seminal fluid. Designations are as for Fig. 1. Peripheral sample wells contained $10 \mu \mathrm{lgG}$-containing fractions or the $<7 \mathrm{~S}$ component of Sample V. Central wells contained the antiserum to (A) whole human serum or (B) human IgG. The precipitin line of identity which formed among all the IgG-containing fractions attests to the antigenic similarity of the semen isolate relative to $7 \mathrm{~S}$ serum IgG. 
PLATE 1

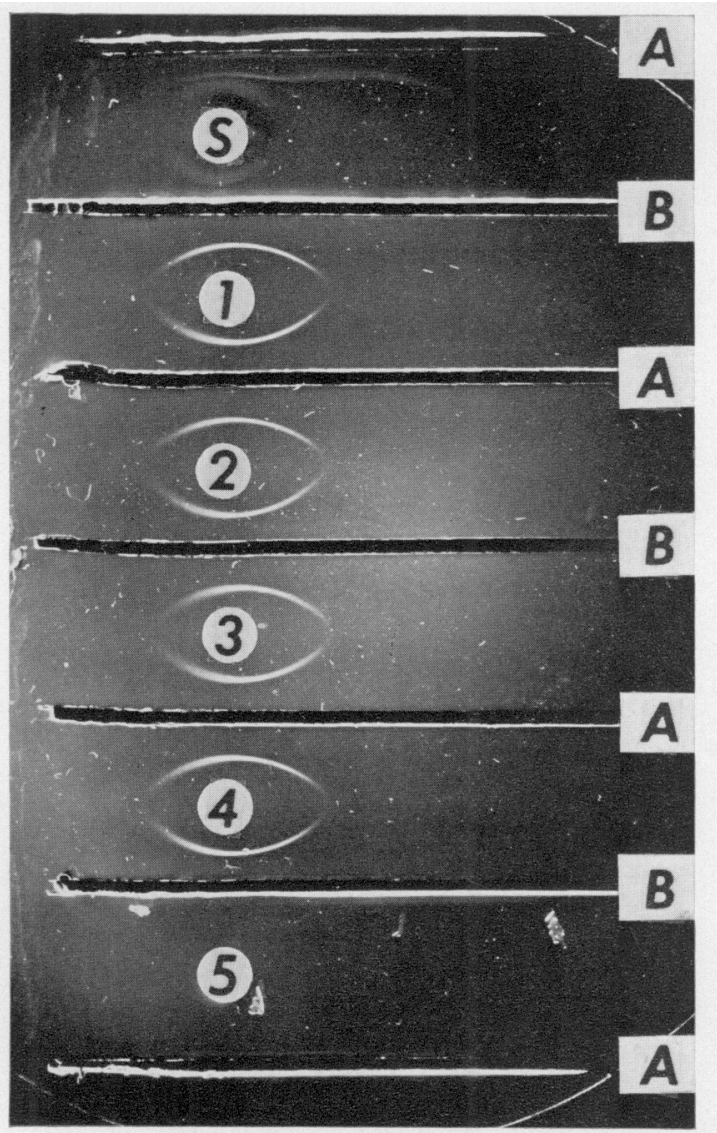

Fig. 1
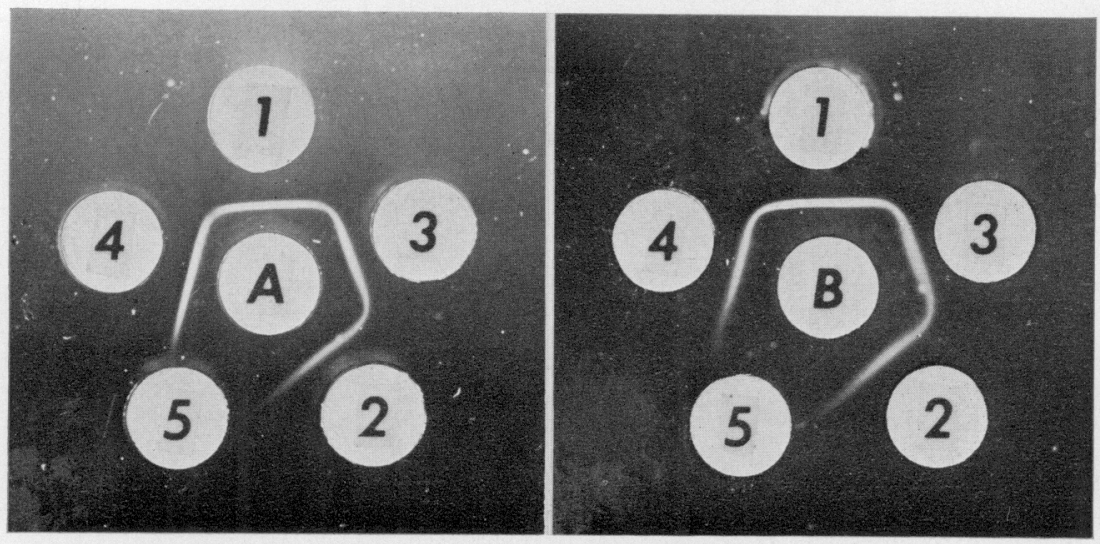

Fig. 2 
Table 2. The effect of various purified fractions of IgG from the semen of intact and vasectomized ram on seminal fluid DNA polymerase activity*

\begin{tabular}{cccc}
\hline & \multicolumn{3}{c}{ IgG fraction } \\
\cline { 2 - 4 } $\begin{array}{c}\text { Conc. of IgG fraction } \\
(\mu \mathrm{g})\end{array}$ & $\begin{array}{c}\text { Intact men } \\
\text { 7S }\end{array}$ & \multicolumn{2}{c}{ Vasectomized men } \\
\cline { 2 - 4 } & & & $<\mathrm{S}$ \\
\hline 0 & 724 & 701 & 735 \\
8 & - & 692 & 796 \\
9 & - & 370 & - \\
10 & 742 & - & 765 \\
13 & 721 & - & 773 \\
15 & & & \\
\hline
\end{tabular}

\footnotetext{
* As c.p.m. of acid-insoluble product (see text). Duplicate experiments performed on an independent enzyme isolate indicated that 8 and $10 \mathrm{mg}$ concentrations of the $7 \mathrm{~S}$ seminal fluid $\mathrm{IgG}$ from vasectomized men reduced the level of incorporated $\left[{ }^{3} \mathrm{H}\right]$ TTP from 1500 c.p.m. to 930 and 525, respectively, whereas the 7S IgG fraction of semen from intact men was without effect.
}

represented microbial semen contaminants and/or their constituent antigens absorbed onto the spermatozoon. It appears, therefore, that the acquisition after vasectomy of antibodies to sperm nuclear antigen(s), and possibly also to certain acrosomal antigens (Tung, 1976), may reflect true auto-immunization to sperm-specific antigens. Because the DNA polymerases of the sperm nucleus and the seminal fluid are related antigenically (Witkin \& Higgins, 1978), the IgG class of antibodies inhibitory to the seminal fluid polymerase may have arisen as a result of a vasectomy-induced immune response to the sperm nuclear enzyme.

The immunoglobulins in seminal plasma consist mostly of IgG (Edwards, 1976; Friberg \& Tilly-Friberg, 1976), are obtainable in reasonable quantity, and probably enter the seminal plasma by transudation, mainly in the prostate (Rumke, 1974). The serum antibodies directed to sperm nuclear components (Kolk et al., 1974; Tung, 1975) have been identified as IgG and might therefore be expected to find their way into the seminal fluid. Semen rather than serum was selected as the antibody source in the present study because seminal fluid may contain locally produced antibodies (Husted \& Hjort, 1975; Friberg \& Tilly-Friberg, 1976) in addition to serum-derived immunoglobulin (Quinlivan \& Sullivan, 1972; Friberg \& Tilly-Friberg, 1976). Semen-derived immunoglobulins, therefore, should reflect both the general systemic IgG response to sperm antigens following vasectomy and any locally produced IgG which may not be represented in the peripheral circulation.

All of the IgG derived from the semen of intact males sedimented as $7 \mathrm{~S}$ protein. In contrast, approximately $60 \%$ of the protein recoverable from the semen of vasectomized men was considerably smaller than $7 \mathrm{~S}$. This fraction did not inhibit the seminal fluid DNA polymerase activity and was not identifiable in the immunological tests. It may, however, represent IgG fragments degraded to the point of antigenic non-reactivity. Friberg \& Tilly-Friberg (1976) have shown that, despite the considerable proteolytic activity intrinsic to seminal fluid, no degradation of seminal immunoglobulins occurs. Our results with IgG isolated from semen of intact men supports this observation. Whether the formation of this smaller material is an in-vivo consequence of vasectomy or a degradation product of storage in vitro is unknown.

The IgG from Sample $V$ at concentrations of up to $50 \mu \mathrm{g}$ had no effect on the $\mathrm{dT}_{12-18} \cdot \mathrm{rA}$-templated DNA polymerase activity of SSV (data not shown). This indicates that inhibition of the seminal fluid polymerase was antibody mediated and not due to the presence of contaminating protease in the IgG preparations.

Our results indicate that vasectomy leads to the formation of auto-antibodies, not detectable in the semen of the intact males studied, that are capable of inhibiting the activity of the seminal fluid 
DNA polymerase. This inhibition may represent one consequence of auto-immunity after vasectomy. The effect of IgG from the seminal fluid and serum of vasectomized men on the DNA polymerases of spermatozoa and somatic cells is currently being studied.

The specific identity of the seminal fluid DNA polymerase activity is still uncertain. Its ability to utilize the exogenously supplied template-primer $\mathrm{dT}_{12-18} \cdot \mathrm{rA}$ suggests that it is similar to polymerase $\gamma$ and retroviral reverse transcriptase.

We thank the Margaret Sanger Center, Planned Parenthood of New York City Inc., for supplying semen samples and Ms Virginia Barsky for manuscript preparation. This work was supported in part by the National Cancer Institute (Public Health Service grant CA08748); the National Institute of Child Health and Human Development (No. 1 RO1 HD10826-01); and the National Institutes of Health (No. 5SO 7RR05634).

\section{References}

Alexander, N.J. (1975) Immunologic and morphologic effects of vasectomy in the Rhesus monkey. Fedn Proc. Fedn Am. Socs exp. Biol. 34, 1692-1697.

AleXANDER, N.J. (1976) Vasectomy: morphological and immunological effects. In Human Semen and Fertility Regulation in Men, pp. 308-317. Ed. E. S. E. Hafez. C. V. Mosby \& Co., St Louis, Missouri.

AleXander, N.J. (1977) Vasectomy and vasovasostomy in Rhesus monkeys: the effect of circulating antisperm antibodies on fertility. Fert. Steril. 28, 562569.

Alexander, N.J. \& SCHmidT, S.S. (1977) Incidence of antisperm antibody levels and granulomas in men. Fert. Steril. 28, 655-657.

ANSBACHER, R. (1971) Sperm-agglutinating and spermimmobilizing antibodies in vasectomized men. Fert. Steril. 22, 629-632.

Campbell, D.H., Garvey, J.S., Cremer, N.E. \& SusSDORF, D.H. (1970) Isolation of rabbit antibodies and their subunits. In Methods in Immunology, pp. 183-234. W. A. Benjamin, Inc., New York.

CoCHRAN, J.S. (1974) Immunobiology of reproductive processes in men. Urology 4, 367-377.

Coombs, R.R.A., Rumke, Ph. \& Edwards, R.G. (1973) Immunoglobulin classes reactive with spermatozoa in the serum and seminal plasma of vasectomized and infertile men. In Immunology of Reproduction, pp. 354-358. Eds K. Bratanov, R. G. Edwards, V. H. Vulchanov, V. Dikov \& B. Somlev. Bulgarian Academy of Sciences Press, Sofia.

EDWARDS, R.G. (1976) Immunity and the control of human fertility. In Immunology of Human Reproduction, pp. 415-470. Eds J. S. Scott \& W. R. Jones. Academic Press, London.

FriberG, J. \& Tilly-FriberG, I. (1976) Antibodies in human seminal fluid. In Human Semen and Fertility Regulation in Men, pp. 258-264. Ed. E. S. E. Hafez. C. V. Mosby \& Co., St Louis, Missouri.

Hekman, A. \& Rumke, P. (1976) Seminal antigens and autoimmunity. In Human Semen and Fertility Regulation in Men, pp. 245-257. Ed. E. S. E. Hafez. C. V. Mosby \& Co., St Louis, Missouri.

Husted, S. \& HJORT, T. (1975) Sperm antibodies in serum and seminal plasma. Int. J. Fertil. 20, 97-105.

KATSH, S. \& KATSH, G.F. (1977) Immunoreproduction. Life Sci. 20, 761-774.
Kolk, A.H.J., SAmuel, T. \& Rumke, P. (1974) Autoantigens of human spermatozoa. I. Solubilization of a new auto-antigen detected on swollen sperm heads. Clin. exp. Immun. 16, 63-76.

LARdinois, R. \& Page, L.A. (1969) Serum albumin, prealbumin, and post-albumin in perinatal pigs. Devl Biol. 19, 261-280.

Mettler, L., Gradi, T. \& Scheidel, P. (1976) Humoral and cellular response to sperm components. In Human Semen and Fertility Regulation in Men, pp. 268-275. Ed. E. S. E. Hafez. C. V. Mosby \& Co., St Louis, Missouri.

Quinlivan, W.L.G. \& Sullivan, H. (1972) The identity and origin of antigens in human semen. Fert. Steril. 23, 873-878.

Rumke, P. (1974) The origin of immunoglobulins in semen. Clin exp. Immun. 17, 287-297.

Shatkin, A.J. (1969) Colorimetric reactions for DNA, RNA, and protein determinations. In Fundamental Techniques in Virology, pp. 231-237. Eds K. Habel \& N. P. Salzman. Academic Press, New York.

Shulman, S. (1974) Sperm antibodies as a cause of problems in infertility and in vasectomy. In Proc. Ist Int. Congr. Immun. Obstet. \& Gynaec., pp. 41-51. Eds A. Centaro \& N. Carretti. Excerpta Medica, Amsterdam.

TUNG, K.S.K. (1975) Human sperm antigens and antisperm antibodies. I. Studies on vasectomy patients. Clin. exp. Immun. 20, 93-104.

TUNG, K.S.K. (1976) Human sperm antigens and antisperm antibodies. III. Studies on acrosomal antigens. Clin. exp. Immun. 24, 292-299.

Witkin, S.S. \& Bendich, A. (1977) DNA synthesizing activity in normal human sperm: location and characterization of the endogenous reaction. Expl Cell Res. 106, 47-54.

Witkin, S.S. \& Higgins, P.J. (1978) Effects of vasectomy and antisperm antibodies on human seminal fluid DNA polymerase activity. Fert. Steril. 29, 314-319.

Witxin, S.S., Korngold, G.C. \& Bendich, A. (1975) Ribonuclease-sensitive DNA-synthesizing complex in human sperm heads and seminal fluid. Proc. natn. Acad. Sci. U.S.A. 72, 3295-3299. 